\title{
Contributions of the Teaching Assistance Program for the Formation of Engineering Professors: A Survey in a Brazilian Federal University
}

\author{
Fernanda Cristina Barbosa Pereira Queiroz, Flávia Aparecida Barbosa Pereira, \\ Jamil Ramsi Farkat Diógenes, Jamerson Viegas Queiroz, Marciano Furukava \\ The Federal University of Rio Grande do Norte (UFRN), Natal, Brazil \\ Christian Luiz da Silva \\ Federal Technological University of Paraná, Curitiba, Brazil
}

\begin{abstract}
This article aimed to identify whether the introductory course teaching of the Federal University of Rio Grande do Norte (UFRN, Brazil) contributes to the formation of engineering professors. Still, it sought to identify the main teaching and learning methodologies that tutors and teachers used in undergraduate classes, and to identify the assessment tools used by teachers and how the performance of graduate students, teaching as trainees, contributes to the improvement of undergraduate education. As regards the methodological aspects, it is a descriptive research, using quantitative and qualitative approaches, and having target audience students enrolled in graduate programs in engineering of UFRN, who performed the teaching stage and made the introductory course teaching in 2012. The results show that the experience as an intern teaching contributes to developing some skills in graduate students to serve as lecturers in engineering courses.
\end{abstract}

Keywords: professional development program, engineering education, engineering teachers

\section{Introduction}

There is a constant debate in engineering schools in Brazil about the formation of engineering professors, as reported by Bazzo, Pereira, and Linsincen (2000); Matos and Rudolf (2006); Pinto and Oliveira (2006); and Casarim (2012).

Masseto (1998) reported that the French model of higher education implanted in Brazil in 1808, had opted for the domain of knowledge and professional experiences as sole requirements for teaching in upper courses. In the 1950s, the idea of building a developed nation and independent was a watchword, and the federal government, with the creation of Brazilian Coordination of Improvement of Higher Education Personnel

Fernanda Cristina Barbosa Pereira Queiroz, Ph.D., professor, Production Engineering Department, The Federal University of Rio Grande do Norte (UFRN).

Flávia Aparecida Barbosa Pereira, M.Sc., researcher, Applied Center for Management and Innovation, UFRN.

Jamil Ramsi Farkat Diógenes, M.Sc. candidate, researcher, Applied Center for Management and Innovation, UFRN.

Jamerson Viegas Queiroz, Ph.D., professor, Production Engineering Department, UFRN.

Marciano Furukava, Ph.D., professor, Materials Engineering Department, UFRN.

Christian Luiz da Silva, Ph.D., professor, Management and Economics Department, Federal Technological University of Paraná. 
(CAPES), invested in the training of masters and doctors who could contribute to the improvement of the quality of the Brazilian universities. With the National Educational Bases and Guidelines Law (LDB) (Brazilian Ministry of Education, 1996), and currently, with the edition of provisional measures No. 614/2013, reinforced the need for postgraduates to undertake teaching activities in the country.

Thus, the search for professionals with higher degrees, and in some cases, professional causes related to pedagogical skills and political dimensions are not priorities when hiring or evaluating a teacher. There is a fallacy in Brazil that in graduate schools, the graduate masters and doctors with quality, will provide teachers with competences and skills to teach in upper courses.

Specifically in engineering courses, teachers most often begin their activities to finish graduate school and have no training in pedagogical dimension. When hiring teachers, schools favor the curriculum and the technical skills, while the ability to mediate and stimulate students to learn are not considered in many cases.

Given the above information, the question that guided this article was "Does the teaching assistance course for postgraduate students contribute to the formation of engineering professors?”. The main objective of the article was to identify if the introductory course teaching in the Federal University of Rio Grande do Norte (UFRN, Brazil) contributes to the formation of engineering professors. Still, it sought to identify the main teaching and learning methodologies that teachers are responsible for the class use among the students who want to start teaching in engineering and to identify the assessment tools used by teachers and how the performance of graduate students, teaching as trainees, contributes to improving the graduation.

In addition to this introduction section, this article also provided a debate about the formation of the professors for higher education, focusing on teaching skills in engineering and teaching internship. Next, it presented the methodological aspects, pointing out that it is a descriptive research, using quantitative and qualitative approaches and having target audience students enrolled in graduate programs in engineering of UFRN, who performed the teaching stage and made the introductory course teaching in 2012. Last, it presented the results and conclusions.

\section{Professor Formation for the Superior Teaching}

The LDB (Brazilian Ministry of Education, 1996) features about the aspects of the Brazilian educational system, the general principles of school education, the purposes, financial resources, training, and instructions for teachers to develop their activities.

According to the article 13 of the $\mathrm{LDB}$, it is up to the teachers to participate in the preparation of pedagogical proposal of the educational establishment; to develop and fulfill work plans according to the proposal of the pedagogical educational establishment; to ensure students' learning; to establish recovery strategies for the students of lower income; to administer the school days and teaching hours laid down, in addition to participate fully of periods devoted to planning, evaluation, and professional development; and to collaborate with the school's joint activities with families and the community.

Thus, being a teacher is something broad and complex, and goes beyond the transmission of knowledge in the classroom. A teacher must worry about students' learning and being active in the elaboration of pedagogical proposal, recognizing the school as an open institution. According to the article 66 of the LDB, preparation for the exercise of university teaching happens at the postgraduate programs, primarily in Master of Science (M.Sc.) and Doctor of Philosophy (Ph.D.) programs, and in accordance with the provisional measure 614/2013, which corrected articles of the law, that fixed points of Law 2,772, the entry into the teaching profession in Federal 
Institutions of Higher Education (IFES) occurs mostly with doctorates.

According to Pachane (2005), the postgraduates tend to prioritize in their activities to conducting research, becoming responsible for reproducing and perpetuating the belief that to be a professor or to be a good researcher in higher education, it is necessary to know very specific topics.

Therefore, in many cases, there are teachers sleep as students, finish their theses or dissertations, and wake up as teachers. In many courses, especially those more technical as engineering, there exists unpreparedness for the activity of university teaching and total ignorance of the processes of teaching and learning.

\section{Teaching Skills in Engineering}

Traditionally, in Brazil's engineering courses, the teachers were professionals with experience in the profession, who were invited to join the academy according to the status they had in the market. Over the years, due to legal requirements, professor of Brazilian superior teaching is the highest professional title, who devoted years to graduate study and the publication of articles in scientific journals.

These skilled professionals were not trained to be teachers or researchers, but we could imagine that society research and teaching are the same thing. Even researchers believe that they have pedagogical competence to teach, because they were able to learn and develop science and innovation.

The traditional thinking among the teachers in engineering schools is that a good professor is the one who teaches the content of a discipline to students, completely and comprehensively (Alavi-Moghaddam, Taher-Shamsi, \& Maknoun, 2010). These days, the thinking that prevails among the students is that a good professor is the one who makes his/her students to learn aspects of the content of the discipline best suited to their education and their ability of the moment.

... today, if you have a teaching career in which the professionals are experienced or high academic degree holders, giving them technical qualifications for the practice of the profession of engineer or work in research institutes, but not enough to show the exercise of teaching itself. (Pinto \& Oliveira, 2006, p. 2)

Until recently, the largest center of research, production, and dissemination of knowledge was the university itself. Today, with technological changes, students have access to data and information instantly. Most students currently enrolled in the courses were born in an era when it is common for the use of Information and Communication Technologies (ICTs).

There is a trade-off between what a professor believes to be a good class and what a student hopes. “.... the students today note quickly when receiving subjects copied from outdated materials, information reproduced will not add any value to your professional education” (Castanheira \& Ceroni, 2008, p. 118).

Bazzo et al. (2000, p. 23) considered that the specific training to teaching is a key issue for the improvement of the teaching quality of engineering, aiming at overcoming a traditional and conservative model of teaching.

According to Masetto (2003) and Pérez-Foguet, Oliete-Josa, and Saz-Carranza (2005), to act in higher education, teachers must master three essential skills: specifies, pedagogical, and politics. The competence specifies is acquired with fundamental knowledge of the area, with professional experience and development of activities with the productive sector, and with continuing education, attending courses, conferences, and lectures. For pedagogical competence, it can be understood as professionalism in teaching, in which teachers must master four axes: the teaching-learning process, the teacher as designer and manager of the curriculum, 
the understanding of teacher-student and student-student relationships in the process, and the basic theories and practice of educational technology. Political competence comprises the worldview of the teacher, when entering the classroom to teach the content, he/she is a citizen who committed to a society and he/she should be aware of what is happening at the university and beyond.

Thus, Anastasiou and Alves (2003) indicated four skills that a professor must have: personal competence (learning); relational competence (learning to live); productive competence (learning how to do); and cognitive skills (learning to know).

According to Filho (2010), Coca (2013), and Levy-Feldman and Nevo (2013), professors went from knowledge transmitters to mediators of learning. "Currently, classroom strategies are related to a teaching situation which necessarily arises. A teacher becomes a moderator of activities, guiding, leading, and reflecting, not only exposing their ideas” (Castanheira \& Ceroni, 2008, p. 122).

However, there are few who still believe that being a teacher is only to "transmit" knowledge "through certain content" that should be "stored" by the students. This brings us to the scathing criticism of Edgar Morin, resorting to Montaigne, claims that “better a head well” made that well filled. (Rios, 2009, p. 15)

\section{Teaching Internship}

In 1999, the stage of teaching became compulsory for the scholars of social demand of the CAPES as an integral part of the formation of the postgraduate students, aiming at preparation for teaching and undergraduate education qualification. This activity is described in Resolution 065/99, as amended by Resolution 013/00 of CAPES. The standardization of teaching stage activity is contained in Ordinance No. 76, on April 14, 2010, repealing Ordinance No. 52, on September 26, 2002 of the CAPES. The minimum time foreseen for the teaching internship is one semester for scholarship of masters and two semesters for Ph.D. scholarship.

At the UFRN, in accordance with Resolution 063/2010-Higher Council for Research, Education and Extension (CONSEPE), the goals of teaching assistance program (PAD) are to: (a) contribute to the formation of teaching graduate students in master's and doctoral level through academic pursuits at graduation; (b) contribute to the improvement of the quality of teaching in undergraduate courses; and (c) contribute to the articulation between undergraduate and postgraduate studies.

These efforts basically aim to empower the future teachers, so that they can provide positive interactions among teachers, graduate students, and sources of knowledge in classrooms.

According to Schoultz and Hultman (2004), the interaction described in the previous paragraph is of fundamental importance for the formation of college success.

\section{Methodology}

It is a descriptive research using the survey method of quantitative and qualitative approaches.

The following technique involves the standardization of data collection instruments (questionnaires and interviews) that are applied directly to the people of a specific population, whose behaviors and characteristics they desire to know. It is suitable for testing hypotheses, models, and theoretically substantiated propositions (Forza, 2002).

The target audience of this study were the students enrolled in graduate programs in engineering of UFRN, who performed the teaching internship and made the introductory course teaching in 2012. 
The introductory course teaching is an initiative of the postgraduate departament and is offered on the first and second half of each year. In 2012, 16 students have done the course in the first half and 38 students took the course in the second semester.

A semi-structured questionnaire was used for data collection at the end of the stage of teaching. Replies of the questionnaire were received from 35 students, being 22 mainly males and 13 females, with a medium age of 25 years old. The graduate students who answered the survey were enrolled in engineering programs (43\%), mechanical engineering (34\%), chemical engineering (11\%), and electrical engineering (11\%).

\section{Results}

\section{Main Teaching-Learning Strategies Used by the Teachers in the Disciplines, Where the Graduate Students Held the Stage of Teaching}

Generally, classes in engineering courses from UFRN, where postgraduate students have conducted the initial teaching course, used the expository (68\%) strategy. Strategies, like experimentation (11\%), resolution of exercises $(9 \%)$, case studies (7\%), and others $(5 \%)$, such as a debate with the whole class, lectures, and technical visits, were also used.

Older teachers are still using the teaching strategies of the era that made college. (A postgraduate student of chemical engineering)

I realized that the students do not pay attention in class. (A postgraduate of production engineering)

The students love the technical visits and do not value the lecture. If you have a visitor, they want to go, but if they know that the class will have a speaker, they prefer Miss. (A graduate of production engineering)

Effective teachers and substitutes to be engaged should perform an introductory course teaching. (A postgraduate of electrical engeneering)

Many students were the entire class on the Internet by querying the smartphone, and did not pay any attention in class. (A graduate in production engineering)

\section{Main Evaluation Procedures Used}

Individual assessment without consultation is the most widely used assessment tool (70\%), followed by the elaboration of scientific articles (15\%), seminars (10\%), and lists of exercises (5\%).

Overall, $90 \%$ of the teachers did not use the result of the evaluation to review the content to be taught and $70 \%$ did not disclose the expected result.

The teacher does not use the result of evaluating for nothing, just asked me to provide feedback to students. (A postgraduate of mechanical engineering)

Valuations are prepared and do not have an expected response pattern, the teachers asked us to correct the proofs and had not thought of the possible answers, and a few times, the question was poorly worded. (A postgraduate of mechanical engineering)

\section{Use of Any Technological Education Resource}

Eighty-nine percent of the teachers use technological education resources to support the university's academic system classes for provision of materials and information, and $82 \%$ of the teachers have requested aid from graduate students to make available information on the academic system and also in social media, like Facebook and Twitter.

All four graduate students who worked in laboratory disciplines helped the teacher in preparing the content and practical demonstrations in the classroom. Two graduate students in the disciplines introduced software that teachers have not used. 


\section{Contribution of the Stage for the Formation of Engineering Professors}

The students evaluated positively the course and the teaching internship (92\%). In the view of graduate students in engineering, the experience helped to develop some skills and competences to act as a teacher, such as teaching and learning techniques (74\%), planning of lessons (51\%), body language (29\%), way to communicate (29\%), knowledge of procedures for elaboration of evaluation (26\%), decreased fear of exposing themselves in public (14\%), ability to make decisions (11\%), and improvisation (6\%).

Act in the classroom as a student is to have a one-sided view of what really happens in the room, to have the opportunity to experience the other side, the teacher, with the help of a tutor, and to make us rethink the value and significance of the profession. (A postgraduate of production engineering)

The course contributed to encouraging even more the professor. I had no idea that teaching also includes the motivation of students, the concern with the dialogue, and the inclusion. (A postgraduate of electrical engineering)

\section{Contribute to Improving the Graduation Stage}

The internship allowed the undergraduates to have an extra support for questions (60\%), contributed to awakening in the undergraduate students' interests in attending graduate schools (30\%) and motivating teachers to adopt new learning and teaching strategies (18\%).

Given the proximity of the ages (mine and the pupils) and my fresh out of graduation, I had a better language ability and ended up favoring the communication with students. (A postgraduate of mechanical engineering)

Practically, I followed the teacher in every class and learned a lot from his methodology. (A postgraduate of electrical engineering)

\section{Scholars' Relationship With the Teacher of the Discipline}

The postgraduate students evaluated the guiding teachers positively. Ninety-two percent of the respondents reported that the professor was very receptive and provided assistance in the class progress.

Only one of the 35 respondents had a conflict with the teaching of the discipline, because the teacher did not allow the graduate student to had contact with the students and limited that student to conduct the planning lessons and review the activities.

\section{Conclusions}

In spite of that the higher education sector has experienced a high growth between 1990 and 2000, driven mainly by private higher education institutions, and more recently, public universities, with the program of restructuring and expansion of federal universities, there are deficiencies in the formation of engineering professors.

With respect to the objectives proposed for the work, it is possible to agree that they were completed, insofar as it has been developed and applied an instrument, allowing to identify the contributions of the introductory course teaching of teacher training in engineering of UFRN. It was pointed out that the work has identified the main teaching and learning methodologies that teachers are responsible for the classes use, as well as the assessment tools used by teachers.

The method was shown to be able to assist in the responses of the proposed objectives, and respond to the research problem, to the extent that identified as the course teaching assistance for graduate students, contributing to the formation of engineering professors.

The results obtained in the research were allocated into six large groups:

The first is about the main teaching-learning strategies used by teachers, pointing out that $68 \%$ of the 
classes are expository;

The second is about the main evaluation procedures used, showing that $70 \%$ of the evaluations are individual;

The third is about the use of some resources of technological education, pointing out that $89 \%$ of the teachers use them to support classes;

The fourth is about the university's academic system for provision of materials and information, showing that $82 \%$ of the teachers have requested aid from graduate students to make available information on the academic system and also in social media, like Facebook and Twiter;

In the fifth stage, regarding the contribution to the teacher education of the graduate students, $92 \%$ of the students assessed the internship course positively. With regard to assistance from the stage to improve graduation, $60 \%$ answered that the stage allowed the undergraduates to had an extra support to take questions;

In the last step, concerning the graduate students' relationship with the teacher of the discipline, $92 \%$ of the respondents reported that the professor was very receptive and allowed the postgraduate students to help in the progress of the discipline.

These results highlight the importance of the introductory course teaching for the training of teachers in engineering and suggest proposals for future work, compared to the practices adopted by graduate students from the UFRN with other IFES of Brazil and abroad.

\section{References}

Alavi-Moghaddam, M. R., Taher-Shamsi, A., \& Maknoun, R. (2007). The role of environmental engineering education insustainable development in Iran. International Journal of Sustainability in Higher Education, 8(2), 123-130.

Anastasiou, L. G. C., \& Alves, L. P. (2003). Processes of teaching and learning at university: Assumptions for strategies work in the classroom (Unpublished Ph.D. thesis, Univille University, Brazil).

Baeta, A. A. (1999). Document 028/99/PR. Brasilia, Brazil: Brazilian Coordination of Improvement of Higher Education Personnel.

Bazzo, W. A., Pereira, L. T. V., \& Linsincen, I. V. (2000). Technological literacy: Approach to engineering education. Florianópolis: EdUFSC.

Brazilian Ministry of Education. (1996). National educational bases and guidelines law. Brasilia, Brazil: Brazilian Ministry of Education.

Casarim, S. J. (2012, September 5). The engineer professor: Limitations and possibilities. Proceedings of The Brazilian Congress of Engineering Teaching-Cobenge 2012, Belem, Brazil.

Castanheira, A. M. P., \& Ceroni, M. R. (2008). Lecturer and new vision of educational assessment training. Estudos em Avaliação Educacional, 19, 39.

Coca, D. M. (2013). The influence of teaching methodologies in the learning of thermodynamics in secondary education. Journal of Baltic Science Education, 12(1), 59-72.

Filho, W. L. (2010). Teaching sustainable development at university level: Current trends and future needs. Journal of Baltic Science Education, 9(4), 273-284.

Forza, C. (2002). Survey research in operational management: A process-based perspective. International Journal of Operations \& Productions Management, 22(2), 152-194.

Levy-Feldman, I., \& Nevo, D. (2013). Perception of the accomplished teacher among teacher educators in "research oriented” and “teaching oriented” institutes in Israel. Studies in Educational Evaluation, 39(3), 153-160.

Masetto, M. (1998). Teaching at the university. Campinas: Papirus.

Matos, L. F. S., \& Rudolf, E. C. A. (2006, September 14). LDB and the formation of the engineer-teacher. Proceedings of The Brazilian Congress of Engineering Teaching-Cobenge 2006, Passo Fundo, Brazil.

Oliveira, M. L. C., \& Silva, N. C. (2012). Stage of teaching in the master's in nursing education: An experience report. Enfermagem em Foco, 3, 131-134. 
Pachane, G. G. (2005, September 25). Internship program and teacher training: The experience of training of university teachers at UNICAMP. Proceedings of The VIII Congress on State Public Educator Training UNESP, São Paulo, Brazil.

Pérez-Foguet, S., Oliete-Josa, A., \& Saz-Carranza, A. (2005). Development of education and engineering: A framework for incorporating reality of developing countries into engineering studies. International Journal of Sustainability in Higher Education, 6(3), 278-303.

Pinto, D. P., \& Oliveira, V. F. (2006). Reflections on the practice of professor. Proceedings of The Brazilian Congress of Engineering Teaching-Cobenge 2006, Passo Fundo, Brazil.

Reis, C. A. C. (2008). Teacher education in engineering. Cefet, Brazil: Minas Gerais.

Rios, T. A. (2009). Ethics in college teaching: Towards a pedagogic university. São Paulo, Brazil: Cadernos Pedagogia Universitaria.

Schoultz, J., \& Hultman, G. (2004). Science teaching and the school—When concepts meet context. Journal of Baltic Science Education, 3(2), 22-33. 